University of Nebraska - Lincoln

DigitalCommons@University of Nebraska - Lincoln

Sociology Department, Faculty Publications

Sociology, Department of

$5-2010$

\title{
Specifying the effects of religion on medical helpseeking: The case of infertility
}

Arthur L. Greil

Alfred University, fgreil@alfred.edu

Julia McQuillan

University of Nebraska-Lincoln, jmcquillan2@Unl.edu

Maureen Benjamins

Sinai Urban Health Institute, Chicago, IL

David R. Johnson

Pennsylvania State University, drjlks@yahoo.com

Katherine M. Johnson

Pennsylvania State University

See next page for additional authors

Follow this and additional works at: https://digitalcommons.unl.edu/sociologyfacpub

Part of the Sociology Commons

Greil, Arthur L.; McQuillan, Julia; Benjamins, Maureen; Johnson, David R.; Johnson, Katherine M.; and Heinz, Chelsea R., "Specifying the effects of religion on medical helpseeking: The case of infertility" (2010). Sociology Department, Faculty Publications. 109.

https://digitalcommons.unl.edu/sociologyfacpub/109

This Article is brought to you for free and open access by the Sociology, Department of at DigitalCommons@University of Nebraska - Lincoln. It has been accepted for inclusion in Sociology Department, Faculty Publications by an authorized administrator of DigitalCommons@University of Nebraska - Lincoln. 


\section{Authors}

Arthur L. Greil, Julia McQuillan, Maureen Benjamins, David R. Johnson, Katherine M. Johnson, and Chelsea R. Heinz 
Published in Social Science \& Medicine (2010); doi: 10.1016/j.socscimed.2010.04.033

Copyright () 2010 Elsevier Ltd. Used by permission. http://www.elsevier.com/locate/socscimed

This research was supported in part by grant R01-HD044144 “Infertility: Pathways and Psychosocial Outcomes" funded by NICHD. Dr. Lynn White (University of Nebraska-Lincoln) and Dr. David R. Johnson (The Pennsylvania State University) were Co-PIs on the first wave of data collection.

Published online May 24, 2010.

\title{
Specifying the effects of religion on medical helpseeking: The case of infertility
}

\author{
Arthur Greil, ${ }^{1}$ Julia McQuillan, ${ }^{2}$ Maureen Benjamins, ${ }^{3}$ \\ David R. Johnson, ${ }^{4}$ Katherine M. Johnson, ${ }^{4}$ and Chelsea R. Heinz ${ }^{1}$ \\ ${ }^{1}$ Alfred University, Alfred, NY, USA \\ ${ }^{2}$ University of Nebraska-Lincoln, Lincoln, NE, USA \\ ${ }^{3}$ Sinai Urban Health Institute, Chicago, IL, USA \\ ${ }^{4}$ The Pennsylvania State University, University Park, PA, USA \\ Corresponding author - A. Greil, Alfred University, Division of Social Sciences, 1 Saxon Drive, \\ Alfred, NY 14802, USA; tel 607 871-2885, fax 607 871-2085; e-mail fgreil@alfred.edu
}

\begin{abstract}
Several recent studies have examined the connection between religion and medical service utilization. This relationship is complicated because religiosity may be associated with beliefs that either promote or hinder medical helpseeking. The current study uses structural equation modeling to examine the relationship between religion and fertility-related helpseeking using a probability sample of 2183 infertile women in the United States. We found that, although religiosity is not directly associated with helpseeking for infertility, it is indirectly associated through mediating variables that operate in opposing directions. More specifically, religiosity is associated with greater belief in the importance of motherhood, which in turn is associated with increased likelihood of helpseeking. Religiosity is also associated with greater ethical concerns about infertility treatment, which are associated with decreased likelihood of helpseeking. Additionally, the relationships are not linear throughout the helpseeking process. Thus, the influence of religiosity on infertility helpseeking is indirect and complex. These findings support the growing consensus that religiously-based behaviors and beliefs are associated with levels of health service utilization.
\end{abstract}

Keywords: Religiosity, Motherhood, Assisted reproductive technology, Medical helpseeking, Ethics, USA, Utilization, Infertility

Decades of research reveal that religiosity generally has positive effects on both mental and physical health (Ellison and Levin, 1998; Koenig and Larson, 2001; Koenig et al., 2001). Researchers are paying increasing attention to the connection between religiosity and medical service utilization as a possible source of the relationship between religion and health (Benjamins, 2006; Hill et al., 2006; King and Pearson, 2003). This relationship is complex. First, the effect of religion on service utilization varies by specific outcome. Second, the impact of religion can work in contradictory directions; different religious beliefs could promote or hinder helpseeking. Third, the effect of religion may not be linear or identical at all stages of the helpseeking process. Finally, it remains unclear which dimensions of religion influence service utilization. In this article, we explore the influence of religion on infertility helpseeking for women who meet the medical definition of infertility - twelve months of unprotected intercourse without conception.

\section{Background}

\section{Religion and service utilization}

Religion has been implicated in reduced mortality, decreased incidence of cardiovascular disease, expedited recovery from illness, and improved mental health (see e.g.; Chatters, 2000; Contrada et al., 2004; Hackney and Sanders, 2003; Powell et al., 2003). The proposed pathways through which religion influences health include encouraging healthy lifestyle habits, providing social support, bolstering self-esteem and self-efficacy, and providing a coherent structure for interpreting life events (George, Ellison, \& Larson, 2002). Differential health care utilization is one possible explanation for the link between religiosity and health. The literature review that follows focuses on religion and service utilization and is not intended to provide a complete review of the extensive literature on religion and health in general.

Studies show that religion is related both to increased and decreased service utilization, depending on the type of service 
and the population examined (see e.g. Benjamins \& Brown, 2003; Benjamins et al., 2006; King and Pearson, 2003; McCullough et al., 2000). In a literature review on religion and health service utilization, Schiller and Levin (1988) found that 24 of 31 studies showed strong religious effects, but they caution that religion is not a unitary phenomenon; religious affiliation, religious salience, denomination, and religious attendance may not have similar impacts on service utilization. Most studies have focused on attendance and salience, and many are quite dated.

In many studies of religion and health services utilization, need for services is a confounding factor. If, for example, religion is negatively associated with doctor visits in a cross-sectional study, does that mean that religion leads to lower service use, or does it simply mean that religious people are healthier and therefore require fewer doctor visits? Focusing on preventive health services may be a partial solution to this issue. Studies investigating religion and the use of preventive health services show some positive associations. More frequent religious attendance is associated with increased likelihood of blood pressure screening (Benjamins, 2007; Felix-Aaron et al., 2003), diabetes screening (Benjamins, 2007), cancer screening (Benjamins, 2006); cholesterol screening (Benjamins, 2005, 2006), and regular checkups (Hill et al., 2006). Results, however, are inconsistent. For example, other studies fail to find associations between frequency of attendance and cholesterol screening (Benjamins, 2007), cancer screening (Fox et al., 1998), and regular checkups (Ellison et al., 2008).

Studies of the impact of religious salience, or the importance of religion to an individual, reveal similar inconsistencies. Religious salience is positively related to blood pressure screening (Benjamins, 2007), cholesterol screening (Benjamins, 2007; Benjamins and Brown, 2003), cancer screening (Benjamins, 2006; Benjamins and Brown, 2003; Benjamins et al., 2006), and getting flu shots (Benjamins \& Brown, 2004). Yet, a study of older American women found religious salience was not associated with Pap smears or mammograms (Benjamins, 2006), and another study found no association between salience and diabetes screening among older Mexican adults (Benjamins, 2007). Thus, religious salience is often, but not always, associated with preventive service use.

Although a majority of studies indicate that the relationship between religion and health behaviors and outcomes is positive, there is also evidence of a negative association. Religion can influence the types of medical treatment perceived as acceptable: the belief that certain treatments are not supported by religious doctrine may lead to treatment refusal or discontinuation. Some religions forbid or strongly discourage using specific medical devices or procedures such as contraceptives, vaccinations, and blood transfusions (Asser and Swan, 1998; Muramoto, 1999). Increased religiosity could also be associated with lower service utilization because of higher fatalism or external locus of control among those who are more religious (Nagel \& SgoutasEmch, 2007). Individuals with lower personal efficacy and control should be less proactive than those with higher personal efficacy or control (Rodin, 1990; Zarit et al., 2002). These sentiments could lead to an underutilization of health care services, such as those for cancer screening (Straughan and Seow, 1998, 2000). Other researchers, however, have argued that persons with a strong perception of God's control may enjoy more favorable outcomes, especially compared with their counterparts who attribute control to non-religious external forces (Holt et al., 2003a, 2003b; Johnson et al., 2005; Schieman et al., 2006).

The inconsistencies in the prior literature regarding religion and service utilization are not well understood. No clear patterns emerge from the previous studies, with the possible exception that the studies reporting positive associations between re- ligion and preventive service use tend to consist of samples of older people (e.g. Benjamins, 2006, 2007; Benjamins and Brown, 2003). Although we presume that the particular outcome under study should impact the relationship, we see no clear conclusion regarding the association between religion and utilization by type of service studied. Therefore, it is important that future studies include possible mechanisms that can better explain precisely how religion influences utilization.

More information about possible mechanisms is also helpful to better understand the influences that various dimensions of religion, such as religious attendance and salience, could have on service utilization. There are many theoretical reasons why these dimensions would operate differently. Measures of public religious participation, such as attendance, reflect social benefits provided to individuals through involvement with a religious organization. These may include greater access to services and health information and increased motivation to maintain a healthy lifestyle. Individuals who frequently attend religious services have larger social networks, more frequent social interactions, and more frequent (and more types of instrumental and socioemotional assistance than individuals who attend less often or never (Bradley, 1995). Research on the effects of social relationships on a wide range of health behaviors supports the health enhancing benefits of these types of social interactions (Lewis \& Rook, 1999). Religious congregations can also provide normative guidance for individual members, which may increase positive health behaviors (Hoffmann \& Bahr, 2005). Furthermore, religious attendance may also have more direct influences on preventive health care utilization. For example, some churches offer activities or information about health-related topics that may lead (directly or indirectly) to a greater use of health care services by members exposed to these resources. This direct role may help to explain some of the associations found for preventive health services but is expected to be less relevant to fertility-related services.

The potential explanations for an association between aspects of religion and health care use are less clear. Participating in private religious activities (e.g. prayer or reading religious texts), holding religious beliefs, and considering religion to be important in one's life may all impact service utilization through various pathways. Although limited, most research on this topic involves the influence of religious beliefs in encouraging positive health behaviors. Most of the findings, however, do not support such a relationship. For example, among Presbyterians, there was no support for the mediating role of the belief in a responsibility to God to maintain one's health and a belief in the connection between spiritual and physical health (Benjamins et al., 2006). Another study found that beliefs in the sanctity of the body are actually associated with a decreased likelihood of having a routine health exam in the past year (Ellison et al., 2008). In contrast, Mahoney et al. (2005) found that sanctification of the body predicted positive health practices in college students. The influence of prayer and possible explanations for the impact of salience are also understudied; therefore there needs to be more work in this area.

Thus, although religion is associated with service utilization, it is difficult to succinctly characterize the relationship. Previous studies show generally positive, though not consistent, associations with utilization that cannot be explained by differing samples or outcomes. It is also not clear what characteristic or quality of religion is related to helpseeking. The impact of religion may be due to selection, better health of religious individuals, social support and capital from religious participation, specific health initiatives undertaken by certain religious organizations, or content of religious beliefs or specific theologies (Ellison et al., 2008). We address these limitations by extending the literature 
to another health service outcome of interest; by examining two distinct aspects of religion; and by investigating the role of potential mediators.

\section{Infertility and helpseeking}

We assess the relationship between religiosity and health behavior via infertility helpseeking. The prevalence of infertility worldwide was recently estimated at $9 \%$ (Boivin et al., 2007). According to the National Survey of Family Growth (NSFG), 15\% of U.S. women reported "impaired fecundity" in 2002 (Chandra et al., 2005), but lifetime prevalence rates are considerably higher. A probability-based sample of women in 12 Midwestern states found that $38 \%$ of women aged 25 to 45 reported infertility at some point in their lives (White et al., 2006).

Studies describe infertility as a devastating experience that brings feelings of emotional distress and a high level of commitment to treatment-seeking, especially among women (Becker, 2000; Greil, 1991; Sandelowski, 1993). Given this characterization, it is surprising that less than half of infertile women seek medical treatment (Boivin et al., 2007; Chandra and Stephen, 1998). Of the infertile women studied in Wave 1 of the National Survey of Fertility Barriers (NSFB) (the dataset we use for this paper), $27 \%$ had visited a doctor concerning fertility problems, $21 \%$ more had gone on to have tests or treatment, and $3 \%$ had undergone in vitro fertilization (IVF) or other assisted reproductive technologies (ART) (Johnson \& White, 2009).

Examining infertility helpseeking expands the study of religion and service utilization beyond health-related preventative behaviors. First, it is a condition with a high incidence but a relatively low treatment rate. In addition, many people do not seek help for infertility soon enough for treatment to be optimally effective. Second, infertility treatment is largely voluntary; it is rarely life-threatening and health professionals usually learn of it only when brought up by patients. It is a condition that need not be interpreted medically and for which many people do not, in fact, seek medical solutions. Finally, religion may be particularly salient for these types of decisions because religious traditions and beliefs are strongly connected to family and life course issues such as fertility.

Most religious traditions encourage child-bearing and emphasize the importance of family during services and other activities. Studies that find that higher religiosity is associated with lower acceptance of childlessness (Bulcroft and Teachman, 2004; Koropeckyj-Cox and Pendell, 2007) and higher fertility intentions (Hayford \& Morgan, 2008). Research suggests that people with strong religious beliefs tend to be more traditional in lifestyle choices, gender ideology, and marriage and family patterns (Grasmick et al., 1990; Jensen and Jensen, 1993), and this may encourage the pursuit of infertility treatment.

Importantly, many of the advances in reproductive technology are discouraged or prohibited by religious traditions. Religious officials are concerned with two main issues - the sanctity of the marital relationship and the sanctity of the embryo (for reviews, see Dutney, 2007; Schenker, 2005). For some denominations, such as Roman Catholicism, this results in opposition to the use of artificial insemination (including intra-uterine insemination (IUI) and in vitro fertilization (IVF)) (Congregation for the Doctrine of the Faith, 1987). Protestantism, Judaism, and Islam have slightly fewer restrictions than Catholicism; these traditions generally approve of advanced reproductive technology (ART), but they are against the use of donor gametes (Dutney, 2007). Perhaps for these reasons, religious individuals may choose to avoid such technologies and favor alternatives such as adoption. In fact, religious salience is associated with increased likelihood of seeking to adopt (Hollingsworth, 2000). Thus, the relationship between religion and infertility helpseeking is expected to be complex.

Finally, it is important to address factors relevant to infertility helpseeking. Women with primary infertility (no prior pregnancies) are more likely to seek help than are those with secondary infertility (Hirsch and Mosher, 1987; Schmidt and Munster, 1995). Greil and McQuillan (2004) and Jacob et al. (2007) showed the importance of considering pregnancy intentions at the time of the infertility episode. They categorized infertile women into two groups: "infertile with intent" (women who say they tried to conceive for at least 12 months without conception) and "infertile without intent" (women who report having had unprotected intercourse for a year or more without conception but who do not say that they were trying to conceive at the time). The infertile with intent are significantly more likely to seek treatment than the infertile without intent (White et al., 2006). Other factors associated with infertility helpseeking include wanting another child, higher income and education, and having private health insurance (Greil and McQuillan, 2004; Greil et al., 2009; White et al., 2006). Greil et al. (2009) found that Hispanic women were less likely to seek help even after a large array of other factors were controlled.

\section{Statement of the problem}

Our goal is to assess the influence of various aspects of religiosity on infertility helpseeking. There are reasons to expect that religiosity should impact infertility helpseeking. First, there is a generally positive association between religiosity and service utilization, previously discussed, that suggests religious women may be more likely to utilize health services. In addition, because many religions embrace pronatalist ideals, motherhood may be more important to more religious women; this should increase religious women's likelihood of helpseeking if they experience fertility barriers. Certain religious beliefs, however, could also lead to fatalism. Religiosity may also increase ethical concerns about fertility treatment. We hypothesize that these two countervailing, mediating forces, importance of motherhood and ethical concern, will cancel each other out and that there will be no significant net effect of religiosity on infertility helpseeking. Figure 1 presents a schematic drawing of our basic theoretical model.

\section{Methodology}

\section{Sample}

Our data come from the NSFB, a national random-digit-dialing telephone survey we designed to assess social and health factors related to reproductive choices and fertility for U.S. women. Between September 2004 and December 2005, we completed

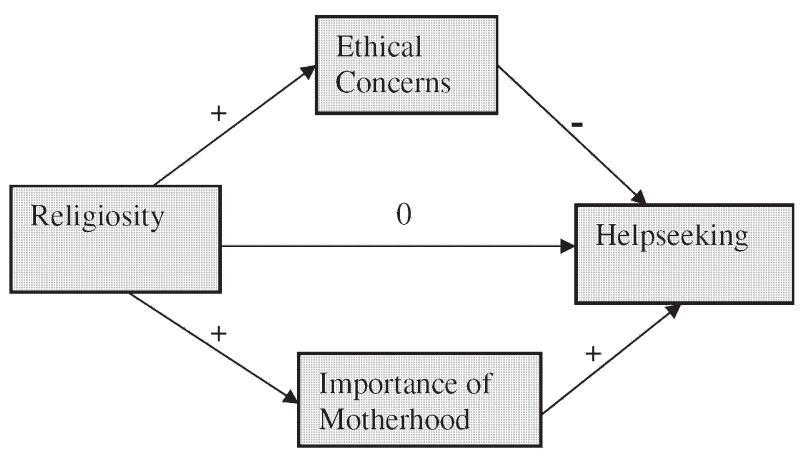

Figure 1. Basic theoretical model. Note: " 0 " indicates that no effect is anticipated. 
interviews with 4712 women ages 25 to 45 . We draw our data from 2183 women who reported experiencing an infertility episode at some point in their lives. Although the NSFB also included interviews with a subsample of male partners, we did not include men in this analysis because it would have significantly reduced our sample size $(n=926)$ and analyses of the NSFB data have shown that male partners who responded to the survey represent a more select group of men (Johnson \& White, 2009). For the purposes of this study, we were interested in the relationship between religion and helpseeking in a more representative group of women. Additionally, studies have shown that women are typically the more instrumental partner when a couple experiences infertility, taking responsibility for initiating helpseeking or treatment (Greil, 1991; Throsby and Gill, 2004).

Sampling procedures and selection criteria were used to ensure an adequate representation of women from racial/ethnic minority groups, women who have experienced infertility, and women who desire additional children. Ethics approval was provided by the University of Nebraska at Lincoln and the Pennsylvania State University Because the survey was long (potentially taking over $45 \mathrm{~min}$ to complete), we shortened it by randomly assigning participants to two-thirds of the items of each scale. This "planned missing" design provided a way to incorporate measures of all of the necessary theoretical concepts while minimizing respondent burden. This type of missing data fulfills the 'missing completely at random' (MCAR) assumption and does not bias results (Allison, 2002). We used the mean of available scale items in the analyses. The response rate for this sample is $53 \%$ for the screener and $37.2 \%$ overall. This response rate is typical for telephone surveys conducted in the last several years (McCarty et al., 2006). Recent studies have shown that surveys with lower response rates are not necessarily more biased than higher response rate studies (Keeter et al., 2006). To assess representativenes we compared it to the National Survey of Family Growth (NSFG), a population-based survey with a response rate close to $90 \%$, and found very similar responses to equivalent fertility-specific and demographic questions in the two surveys.

\section{Concepts and measures}

Our main outcome is infertility helpseeking. Respondents were asked a series of questions about information-seeking, treatment-seeking, tests, and treatments related to infertility. From these, we constructed an ordinal variable with six values: (0) did not seek help (1) considered treatment; (2) talked to a doctor; (3) had tests; (4) received treatment; and (5) had ART. Anyone at a higher value has satisfied the conditions for all lower values. For example, anyone who has had tests has also talked to a doctor and considered treatment. Of the infertile women studied in Wave 1 of the NSFB, 63.4\% reported not seeking help, 8.9\% reported "considered only," $7.0 \%$ saw a doctor only, $7.0 \%$ had tests but did not move on to treatment, $10.7 \%$ received conventional treatment only (such as artificial insemination or fertility drugs to stimulate ovulation), and $2.7 \%$ had some form of assisted reproductive technology (ART), involving manipulation of both egg and sperm outside of the body.

We used two main variables to capture religious involvement and belief: religiosity and religious attendance. Religiosity was measured by three questions: 1) "About how often do you pray," 2) "How close do you feel to God most of the time," and 3) "In general, how much would you say your religious beliefs influence your daily life?" The items formed a single factor with high reliability $(a=.77)$. This was treated as a latent variable in our model. Religious attendance was assessed via a single question: "How often do you attend religious services?" Possible responses included: "never," "less than once a year," "about once or twice a year," "about once a month," "nearly every week," "every week," and "several times a week." The Pearson's r between religiosity and attendance is .274 . We did not include a measure of religious denomination because a sufficiently detailed measure was not available to us.

\section{Mediating variables}

Our focal mediating variables were importance of motherhood and attitudes toward the ethics of ART. Both were treated as latent variables in our model. Importance of motherhood was constructed by averaging responses to five questions. Four items were measured using Likert scales (strongly agree to strongly disagree): 1) "Having children is important to my feeling complete as a woman," 2) "I always thought I would be a parent," 3) "I think my life will be or is more fulfilling with children," and 4) "It is important for me to have children." A fifth item was measured on a scale from very important to not important: "How important is each of the following in your life...raising children?" Higher scores indicate greater importance of motherhood. Factor analyses showed that these items formed a single factor that explained $64 \%$ of the variance $(a=.86)$. Attitudes toward the eth$i$ ics of ART is a scale assessing the respondent's concern with six instances of ART (alpha = .86): 1) insemination with husband's sperm, 2) insemination with donor sperm, 3) in vitro fertilization, 4) use of donor eggs, 5) surrogate mothering, and 6) using a gestational carrier. Each item had three ordered response categories indicating no, some, or serious ethical problems.

\section{Control variables}

A number of variables that have been shown to influence infertility helpseeking were included as controls in the analyses. Women who described themselves as trying to become pregnant at the time of their infertility episode were classified as infertile with intent, while women who did not report themselves as actively trying to become pregnant during their infertility episode were classified as infertile without intent. Respondents were classified as having primary infertility if they experienced a period of infertility before they had experienced any pregnancies. All other women were classified as having secondary infertility. Wants another child was coded 1 for those responding 'yes' to the question: "Would you, yourself, like to have (another) baby?" Age was measured in years. Due to people's sensitivity to questions about income, family income was first constructed as an ordinal scale ranging from 1 (less than $\$ 5000$ per year) to 12 ( $\$ 100,000$ or more). We then substituted the midpoint of each category for the category value in order to convert this into a continuous scale. Education was measured in years. Private health insurance status was assessed by the question, "Are you covered by private health insurance, by public health insurance such as Medicaid, or some other kind of health care plan or by no health insurance?" Respondents with private health insurance were coded as 1 while all other options were coded as 0 . Public health insurance is appropriately classified with no insurance because infertility benefits are not covered by Medicaid in the U.S. (Bittler \& Schmidt, 2006). Dummy variables for race were constructed for Black, Hispanic, and Asian compared to non-Hispanic White women and women who listed their race as "other." We collapsed the latter two because the small "other" group did not differ significantly from non-Hispanic White women with regard to the variables of interest.

\section{Method of analysis}

Figure 2 displays our full structural equation model. Our final dependent variable was infertility helpseeking. Religiosity was conceptualized as having indirect effects on helpseeking through religious attendance, ethical concerns, and importance 


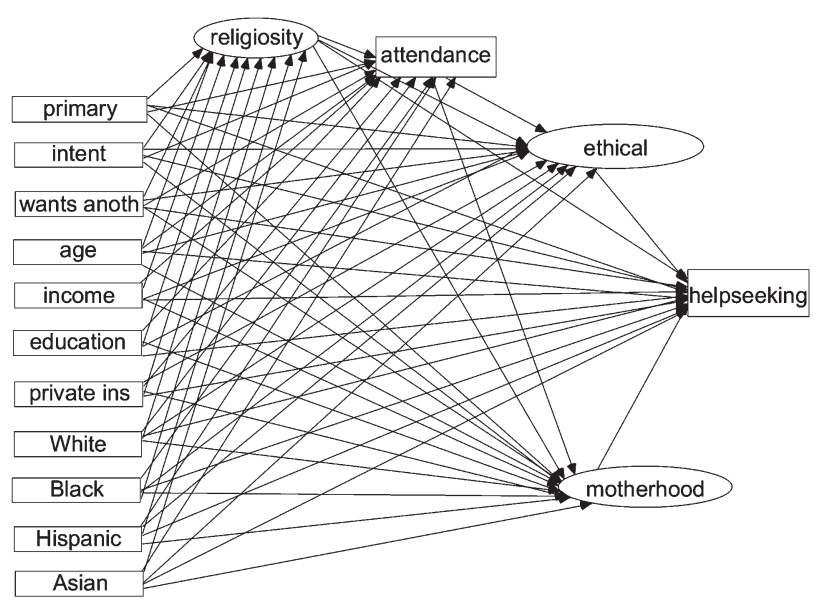

Figure 2. Elaborated SEM model.

of motherhood. Although we have hypothesized that religiosity would not have a direct effect on helpseeking, we retained the direct path in the model to test for this possibility. The ethics of ART and the importance of motherhood were included as latent variables with the items in each scale serving as the multiple indicators of the respective underlying constructs. All of the paths from the control variables to the focal variables in the model were left unconstrained in order to take into account the possible effects of the control variables on the focal variables.

We were restricted from using the common basic linear structural equation model both because our main outcome variable was ordinal and because we are interested in testing if the religiosity effects varied by treatment level. If the effects of the explanatory variables were the same at each level of helpseeking then an ordinal logistic regression model would be more parsimonious as only one coefficient for each variable would be needed. Ordinal logistic regression is appropriate only when the parallel lines assumption, also referred to as the proportional odds assumption, is met (Winship \& Mare, 1984). This requires that the slopes predicting values of the dependent variable be parallel for every level of the dependent variable (Brant, 1990). The parallel lines assumption did not hold for our model so we treated helpseeking as a series of discreet stages rather than as a single ordinal variable. We followed the example of Williams (2006) and conducted five separate structural equation models with binary outcomes to estimate the effects of religiosity at each transition in the helpseeking process. All cases were included in each model; only the cut point was changed. For example, the first analysis included all women and compared those who did not seek help with all women at later stages (considered helpseeking and beyond), while the second analysis also includes all women but uses whether women actually saw a doctor as the cut point. The analysis was done with the full information maximum likelihood estimation method which uses all cases even if some variables have missing data.

\section{Results}

Table 1 shows descriptive statistics by each stage of helpseeking. For ease of presentation, continuous variables in our final model have been broken into categories. Women who have progressed to different stages of the helpseeking process appear to differ across all of the independent variables in the model. Thus, there is good reason to include these variables in an analysis of the relationship between religiosity, religious attendance, ethical concerns, importance of motherhood, and helpseeking.
The results of the series of analyses are in Table 2 . For ease of presentation, we have not displayed the control variables (available upon request). Although the $\chi^{2}$ is significant in all analyses, other fit statistics are within the prescribed limits, suggesting that the model fits the data adequately. Neither religiosity nor religious attendance was associated with helpseeking in any of the analyses. Ethical concern about reproductive technology was negatively associated with helpseeking at all stages of the treatment process except the transition to ART; for this latter comparison, this may be due low statistical power because the effect size remains large $(\mathrm{OR}=.60)$. The relationship is strongest when comparing tests and lower stages of helpseeking to being treated. Increased ethical concerns reduces the odds of moving to the treatment stage by a factor of over three $(\mathrm{OR}=.30)$. Thus, the influence of ethical concerns on helpseeking can be observed throughout the helpseeking process but is strongest at the point where women move from lower stages of helpseeking to actually undergoing treatment.

Importance of motherhood was associated with increased odds of helpseeking, but only at two stages of the treatment process: when women moved between seeing a doctor and all lower stages of helpseeking to actually having medical tests $(\mathrm{OR}=1.25)$ and between conventional treatment and lower stages to ART $(\mathrm{OR}=1.43)$. Thus, the importance of motherhood plays a role at two crucial points in the helpseeking continuum where women must commit to undergoing invasive and time-consuming procedures. Having primary infertility and being infertile with intent were both associated with higher odds of proceeding to the next stage of helpseeking for all analyses. Stronger desire to have a child and having private insurance increased the odds of being in the next level of helpseeking in the early stages of the process. Age was relevant to helpseeking in the middle of the process. Race and income both were associated with helpseeking in the later stages of helpseeking. Our analysis accounts for about half of the variation in helpseeking (pseudo$\mathrm{R}^{2}$ ranges from .441 to .547).

We turn now to the mediating variables: ethical concern and importance of motherhood. Religiosity was not related to ethical concerns about infertility treatment in any of the analyses, but religious attendance was positively associated with ethical concerns, regardless of helpseeking stage. In other words, women with higher levels of religious attendance were more likely to express ethical concerns about assisted reproductive technology. Additionally, Black, Hispanic, and Asian women express greater ethical concerns about infertility treatment than non-Hispanic White women and those who identify as members of other races.

As hypothesized, higher religiosity was associated with higher importance of motherhood in all five analyses. Women with primary infertility had lower importance of motherhood scores than women with secondary infertility. Women who were infertile with intent and women who reported wanting a (nother) child had higher importance of motherhood scores. Higher age was associated with lower importance of motherhood in all analyses. Black and Hispanic women scored lower on importance of motherhood than other women. Our analysis accounted for approximately one eighth of the variation in importance of motherhood $\left(R^{2}=.135\right)$. Religiosity was strongly associated with religious attendance in all analyses. Thus, although religiosity was not associated with ethical concerns directly, it was associated with religious attendance, which in turn was associated with ethical concerns. Higher income and education were associated with higher religious attendance in all analyses, but with lower religious beliefs in all analyses. Black and Hispanic women have higher religiosity scores than non-Hispanic White women and women of "other" races in all analyses. 
Table I. Descriptive statistics by categories of helpseeking.

\begin{tabular}{|c|c|c|c|c|c|c|c|c|}
\hline & $\begin{array}{l}\text { No help } \\
\text { I383\% }\end{array}$ & $\begin{array}{l}\text { Considered } \\
195 \%\end{array}$ & $\begin{array}{l}\text { Talked to doc } \\
153 \%\end{array}$ & $\begin{array}{l}\text { Tests } \\
159 \%\end{array}$ & $\begin{array}{l}\text { Treatment } \\
234 \%\end{array}$ & $\begin{array}{l}\text { ART } \\
59 \%\end{array}$ & p. & $\begin{array}{l}N \text { for row } \\
2183\end{array}$ \\
\hline \multicolumn{9}{|l|}{ Religiosity } \\
\hline Lowest quartile & 21.7 & 28.2 & 28.8 & 33.3 & 19.2 & 32.2 & * & 516 \\
\hline Third quartile & 20.9 & 20.5 & 20.9 & 21.4 & 25.2 & 22.0 & n.s. & 467 \\
\hline Highest quartile & 26.0 & 24.6 & 25.5 & 21.4 & 26.9 & 22.0 & n.s. & 557 \\
\hline \multicolumn{9}{|l|}{ Religious attendance } \\
\hline Primary infertility & 17.7 & 40.5 & 39.2 & 58.5 & 65.1 & 76.3 & $* * *$ & 674 \\
\hline Infertile with intent & 28.0 & 72.2 & 72.4 & 85.5 & 94.4 & 96.7 & $* * *$ & 1053 \\
\hline Wants a(nother) child & 34.3 & 60.8 & 52.3 & 57.6 & 46.5 & 59.3 & $* * *$ & 908 \\
\hline \multicolumn{9}{|l|}{ Age } \\
\hline 25 to 29 & 20.3 & 27.3 & 18.3 & 11.4 & II.I & 5.1 & *** & 409 \\
\hline 30 to 35 & 25.7 & 26.8 & 28.1 & 35.4 & 24.8 & 23.7 & n.s. & 579 \\
\hline Below $40 \mathrm{~K}$ & 50.3 & 46.7 & 43.4 & 36.7 & 30.8 & 12.5 & *** & 991 \\
\hline Education & .0 & .0 & .0 & .0 & .0 & .0 & & \\
\hline Less than $\mathrm{HS}$. & 18.6 & 18.5 & $15 . \mid$ & 12.6 & 11.2 & 3.4 & ** & 365 \\
\hline High school & 32.4 & 25.1 & 37.5 & 22.0 & 28.0 & 16.9 & $* *$ & 665 \\
\hline Some college & 29.9 & 29.7 & 28.9 & 29.6 & 30.6 & 22.0 & $* *$ & 647 \\
\hline College degree or more & 19.1 & 26.7 & 18.4 & 35.8 & 30.2 & 57.6 & *** & 506 \\
\hline Private health insurance & 54.0 & 56.9 & 67.1 & 70.4 & 72.8 & 86.4 & $* * *$ & 1294 \\
\hline \multicolumn{9}{|l|}{ Race } \\
\hline White & 52.7 & 47.1 & 60.8 & 60.4 & 65.6 & 79.7 & $* * *$ & 1210 \\
\hline Black & 23.2 & 22.1 & 16.3 & 16.4 & 7.2 & 5.1 & $* * *$ & 435 \\
\hline Hispanic & 19.5 & 22.6 & 22.9 & 13.8 & 14.9 & 5.1 & * & 409 \\
\hline Asian & 4.9 & 8.2 & .0 & 9.4 & 12.3 & 10.2 & $* * *$ & 134 \\
\hline \multicolumn{9}{|l|}{ Ethical concerns } \\
\hline
\end{tabular}

Chi square tests performed on all variables.

$* p<.05$;** $p<.01$; *** $p<.001$

Table 2. Effects of religiosity on stages of infertility helpseeking $(N=2167)$.

\begin{tabular}{|c|c|c|c|c|c|c|c|c|c|c|}
\hline \multirow[b]{2}{*}{$\begin{array}{l}\text { Dep=religious attendance } \\
\text { Religiosity } \\
R \text { square }\end{array}$} & \multicolumn{2}{|c|}{ Considered } & \multicolumn{2}{|c|}{ Talked to doctor } & \multicolumn{2}{|l|}{ Tests } & \multicolumn{2}{|c|}{ Treatment } & \multicolumn{2}{|l|}{ ART } \\
\hline & $\begin{array}{l}\text { Est. } \\
1.213 \\
.355\end{array}$ & $\begin{array}{c}\text { Beta } \\
.598 * * *\end{array}$ & $\begin{array}{l}\text { Est. } \\
1.210 \\
.354\end{array}$ & $\begin{array}{c}\text { Beta } \\
.598 * * *\end{array}$ & $\begin{array}{l}\text { Est. } \\
\text { I.210 } \\
.355\end{array}$ & $\begin{array}{c}\text { Beta } \\
.598 * * *\end{array}$ & $\begin{array}{l}\text { Est. } \\
\mathrm{I} .202 \\
.356\end{array}$ & $\begin{array}{c}\text { Beta } \\
.599 * * *\end{array}$ & $\begin{array}{l}\text { Est. } \\
I .208 \\
.356\end{array}$ & $\begin{array}{c}\text { Beta } \\
.599 * * *\end{array}$ \\
\hline $\begin{array}{l}\text { Dep=ethical concerns } \\
\text { Religiosity } \\
\text { Religious attendance } \\
\text { R square }\end{array}$ & $\begin{array}{l}\text { Est. } \\
.011 \\
.017 \\
.093\end{array}$ & $\begin{array}{l}\text { Beta } \\
.052 \\
.159 *\end{array}$ & $\begin{array}{l}\text { Est. } \\
.011 \\
.017 \\
.093\end{array}$ & $\begin{array}{l}\text { Beta } \\
.052 \\
.159 * *\end{array}$ & $\begin{array}{l}\text { Est. } \\
.011 \\
.017 \\
.093\end{array}$ & $\begin{array}{l}\text { Beta } \\
.052 \\
.159 * *\end{array}$ & $\begin{array}{l}\text { Est. } \\
.011 \\
.016 \\
.093\end{array}$ & $\begin{array}{l}\text { Beta } \\
.052 \\
.158 * *\end{array}$ & $\begin{array}{l}\text { Est. } \\
.011 \\
.017 \\
.093\end{array}$ & $\begin{array}{l}\text { Beta } \\
.051 \\
.159 * *\end{array}$ \\
\hline $\begin{array}{l}\text { Dep=importance of motherhood } \\
\text { Religiosity } \\
\text { Religious attendance } \\
\text { R square }\end{array}$ & $\begin{array}{l}\text { Est. } \\
.096 \\
.010 \\
.135\end{array}$ & $\begin{array}{c}\text { Beta } \\
.200 * * * \\
.041\end{array}$ & $\begin{array}{l}\text { Est. } \\
.096 \\
.010 \\
.135\end{array}$ & $\begin{array}{c}\text { Beta } \\
.176 * * * \\
.041\end{array}$ & $\begin{array}{l}\text { Est. } \\
.1 \\
.010 \\
.135\end{array}$ & $\begin{array}{c}\text { Beta } \\
.200 * * * \\
.041\end{array}$ & $\begin{array}{l}\text { Est. } \\
.095 \\
.010 \\
.135\end{array}$ & $\begin{array}{l}\text { Beta } \\
.200 * * * \\
.041\end{array}$ & $\begin{array}{l}\text { Est. } \\
.095 \\
.010 \\
.135\end{array}$ & $\begin{array}{c}\text { Beta } \\
.200 * * * \\
.041\end{array}$ \\
\hline $\begin{array}{l}\text { Dep=helpseeking } \\
\text { Ethical concerns } \\
\text { Importance of motherhood } \\
\text { Religious attendance } \\
\text { Religiosity } \\
\text { Pseudo R square } \\
\text { Chi square } \\
\text { CF! } \\
\text { TLI } \\
\text { RMSEA } \\
\text { WRMW }\end{array}$ & $\begin{array}{l}\text { Est. } \\
-.424 \\
.120 \\
.037 \\
-.096 \\
.459 \\
133.993 \\
.961 \\
.956 \\
.019 \\
.905\end{array}$ & $\begin{array}{l}\text { OR } \\
.654 * \\
1.127 \\
1.038 \\
.908\end{array}$ & $\begin{array}{c}\text { Est. } \\
-.477 \\
.114 \\
.022 \\
-.051 \\
.441 \\
132.276 \\
.962 \\
.957 \\
.019 \\
.883\end{array}$ & $\begin{array}{l}\text { OR } \\
.621 * * \\
1.121 \\
1.022 \\
.950\end{array}$ & $\begin{array}{l}\text { Est. } \\
-.689 \\
.222 \\
.045 \\
-.046 \\
.504 \\
136.957 \\
.958 \\
.953 \\
.020 \\
.914\end{array}$ & $\begin{array}{l}\text { OR } \\
.502 * * \\
1.249 * * \\
1.046 \\
.955\end{array}$ & $\begin{array}{l}\text { Est. } \\
-1.219 \\
.173 \\
.024 \\
.116 \\
.547 \\
138.987 \\
.956 \\
.951 \\
.020 \\
.921\end{array}$ & $\begin{array}{c}\text { OR } \\
.296 * * * \\
1.189 \\
1.024 \\
1.123\end{array}$ & $\begin{array}{l}\text { Est. } \\
-.520 \\
.359 \\
-.009 \\
.080 \\
.493 \\
139.565 \\
.957 \\
.951 \\
.020 \\
.917\end{array}$ & $\begin{array}{c}\text { OR } \\
.595 \\
1.432 * * \\
.991 \\
1.083\end{array}$ \\
\hline
\end{tabular}

$* p<.05 ; * * p<.01 ; * * * \quad p<.001$

Helpseeking categories: $0=$ No help; I = Considered; 2 = talked to Doctor; $3=$ Medical tests; $4=$ Infertility Treatment; $5=$ ART Control Variables (primary infertility, infertile with intent, wants a(nother) child, age, income, education, private health insurance, race) not displayed. 
Table 3. Total, Indirect, and direct effects of religiosity on stages of infertility helpseeking.

\begin{tabular}{|c|c|c|c|c|c|c|c|c|c|c|c|c|c|c|c|}
\hline & \multicolumn{3}{|c|}{ Considered } & \multicolumn{3}{|c|}{ Talked to doctor } & \multicolumn{3}{|c|}{ Tests } & \multicolumn{3}{|c|}{ Treatment } & \multicolumn{3}{|c|}{ ART } \\
\hline & Est. & S.E. & Sig. & Est. & S.E. & Sig. & Est. & S.E. & Sig. & Est. & S.E. & Sig. & Est. & S.E. & Sig. \\
\hline Total effects & -.52 & .04 & n.s. & -.03 & .05 & n.s. & -.01 & .05 & n.s. & .13 & .05 & $* *$ & .09 & .06 & n.s. \\
\hline Through attendance & .04 & .04 & n.s. & .03 & .03 & n.s. & .05 & .04 & n.s. & .03 & .04 & n.s. & -.01 & .05 & n.s. \\
\hline Through ethical concerns & s .00 & .01 & n.s. & -.01 & .01 & n.s. & -.01 & .01 & n.s. & -.01 & .01 & n.s. & -.01 & .01 & n.s. \\
\hline Through att, ethics & -.01 & .01 & n.s. & -.01 & .01 & n.s. & .00 & .01 & $*$ & -.02 & .01 & $* *$ & -.01 & .01 & n.s. \\
\hline Through motherhood & .01 & .01 & n.s. & .01 & .01 & n.s. & .02 & .01 & $* *$ & .02 & .01 & n.s & .03 & .16 & $*$ \\
\hline
\end{tabular}

Table 3 further specifies the patterns of associations by providing total, direct, and indirect effects of religiosity on helpseeking. Only in the comparison between treatment and all lower stages of helpseeking is the total effect of religiosity on helpseeking significant. The direct effects of religiosity on helpseeking are not significant in any models. In some analyses, religiosity is associated with lower helpseeking through attendance and ethical concerns, and in others is associated with higher helpseeking through importance of motherhood. These effects, however, cancel each other out in all but one case.

\section{Discussion and conclusions}

The current study is the first we know of that examines the relationship between religion and infertility helpseeking using a nationally representative sample. Religion is not directly related to infertility helpseeking in most analyses, though this does not mean that religion is unrelated to helpseeking. Specifically, the positive effect of religion on helpseeking through the importance of motherhood is counterbalanced by a strong negative impact through increased ethical concerns. The evidence presented here suggests that the relationship between religion and infertility helpseeking is complicated. First, as noted above, religion appears to have both positive and negative impacts on infertility helpseeking. Second, the influence of religiosity on importance of motherhood is direct while the influence of religiosity on ethical concerns is indirect, through religious attendance. Third, the exact nature of the relationship between religion and helpseeking varies at different stages of the helpseeking process. It is only at the stage of moving from all lower stages of helpseeking (i.e., seeing a doctor, contemplating seeking help, not seeking any help) to receiving tests that our hypothesis is confirmed.

Our findings confirm previous research that identifies stronger pronatalist beliefs among religious women (Hayford and Morgan, 2008; Koropeckyj-Cox and Pendell, 2007). Results also lend support to studies indicating increased ethical concerns about medical tests and treatments, such as genetic testing and prenatal tests, among religious individuals (Singer et al., 1998). These conflicting influences result in a lack of an overall relationship, which is at odds with the previous findings that higher religiosity is associated with higher odds of seeking non-necessary medical service utilization. These previous studies on preventive services provide some foundation for the current study, which also examines a "voluntary" health service. The treatments for infertility are debated by religious leaders, however, and in some cases prohibited. Therefore the association between religiosity and medical helpseeking seems to depend upon the specific health issue studied. The relevance of religion for fertility in general and for infertility treatments, therefore, is likely to make helpseeking for this condition unlike many other health conditions.

As noted earlier, the possible mechanisms linking the different dimensions of religion to service utilization could be spe- cific to each dimension. The current study revealed that religiosity is only related to ethical concerns about infertility treatments through attendance. In other words, it is only through involvement at religious services that religious women become more likely to have such ethical concerns. This may reflect individuals who attend more frequently having greater exposure to their religious organization's official position on allowable infertility treatments. In contrast, individuals who have high levels of religiosity but less (or no) involvement with a religious organization may be unaware of such theological debates and stances. In addition, those who attend religious services more frequently may also be exposed to other individuals who disapprove of those choosing to disregard church policies and who may offer support for choosing alternatives in line with the stated positions. Findings regarding the lack of an association between attendance and the importance of motherhood are less easily explained and deserve further exploration.

As with all studies, there are limitations to this project. First, cross-sectional data limit strong conclusions about temporal ordering. We know, for example, that higher ethical concerns are associated with lower levels of helpseeking, but we cannot decisively conclude that ethical concerns cause women to forgo treatments that might be medically appropriate. To make such claims, we need longitudinal data. Wave 2 of the NSFB, now in the field, will provide better temporal ordering and more clarity about the direction of associations. Central concepts (religiosity, importance of motherhood, and ethical concerns) were also measured contemporaneously, after the infertility episode. Therefore is possible that some women may have different attitudes at the time of the survey than they did during the infertility episode. For example, women who had few ethical concerns at the time they decided not to pursue treatment might have developed ethical concerns in retrospect. Here too, data from Wave 2 should help further specify the patterns of associations.

Many of the effect sizes reported here are relatively small. Clearly, we cannot argue that religion accounts for a major portion of the variation in infertility helpseeking. Nonetheless, the study of infertility has been shown to be an appropriate site for demonstrating the complexities of the association between religion and helpseeking. Another limitation of this study is that we were unable to test for the association of religious denomination on infertility helpseeking. This is an important issue to address in future studies.

In addition, more work is necessary to better understand the role of social and cultural factors in helpseeking. To begin, specific information about an individual's religious affiliation would be useful to clarify the theological and social sources of potential ethical concerns. Furthermore, other aspects of the culture in which the infertile individual resides could be expected to influence the relationship between religion and helpseeking. To elucidate these influences, future studies are needed to explore the impact of religion among specific race/ethnic groups 
and within different countries. Additionally, because infertility is often experienced in the context of marriage or other intimate relationships, it may be important to understand how partners' religiosity and religious affiliations either promote or inhibit helpseeking, particularly if partners have differing religious attitudes or dissimilar religious affiliations.

This study has implications beyond the study of infertility. Most generally, it supports the growing consensus that religiously-based behaviors and beliefs are associated with service utilization under specific conditions. For non-life threatening conditions, this study suggests that the meaning of the problem (e.g. importance of motherhood) mediates the association between religiosity and helpseeking. Additionally, if treatments are the topic of religious teaching (e.g. abortion, stem cell therapies), then attitudes about the ethics of these concerns should mediate the effects of religiosity on medical helpseeking. Specifying the associations between religious behavior, religious beliefs, and medical helpseeking shows how meanings of symptoms and outcomes are crucial to understanding medical care. Increasing access to care by reducing cost and increasing coverage are very important, but alone are unlikely to be to meet potential medical care need. It is also important to understand the meaning of symptoms and treatments in order to understand how religion is associated with health service utilization.

\section{References}

Allison, 20024 P. Allison, Missing data, Sage, Thousand Oaks, CA (2002).

Asser and Swan, 1998 S. M. Asser and R. Swan, Child fatalities from religion-motivated medical neglect, Pediatrics 101 (1998), pp. 625-629.

Becker, 20004 G. Becker, The elusive embryo: How women and men approach new reproductive technologies, University of California Press, Berkeley (2000).

Benjamins, 20054 M. R. Benjamins, Social determinants of preventive service utilization: how religion influences the use of cholesterol screening in older adults, Research on Aging 27 (2005), pp. 475-497.

Benjamins, 20064 M. R. Benjamins, Religious influences on female preventive service utilization in a nationally representative sample of older women, Journal of Behavioral Medicine 29 (2006), pp. 1-16.

Benjamins, 20074 M. R. Benjamins, Predictors of preventive health care use among middle-aged and older adults in Mexico: the role of religion, Journal of Cross Cultural Gerontology 22 (2007), pp. 221-234.

Benjamins and Brown, 20034 M. R. Benjamins and C. Brown, Religion and preventative health utilization among the elderly, Social Science \& Medicine 58 (2003), pp. 109-118.

Benjamins et al., 20064 M. R. Benjamins, J. Trinitapoli and C. G. Ellison, Religious attendance, health beliefs, and mammogram utilization in a nationwide sample of Presbyterians, Journal for the Scientific Study of Religion 45 (2006), pp. 597-607.

Bittler and Schmidt, 2006 M. Bittler and L. Schmidt, Health Disparities and infertility: impacts of state level insurance mandates, Fertility and Sterility 85 (2006), pp. 858-865.

Boivin et al., 20074 J. Boivin, L. Bunting, J. Collins and K. G. Nygren, International estimates of infertility prevalence and treatment-seeking: potential need and demand for infertility medical care, Human Reproduction 22 (2007) 1506-1512.

Bradley, 19954 D. E. Bradley, Religious involvement and social resources: evidence from the dataset 'Americans' changing lives, Journal for the Scientific Study of Religion 34 (1995), pp. 259-267.

Brant, $1990<\mathrm{R}$. Brant, Assessing proportionality in the proportional odds model for ordinal logistic regression, Biometrics 46 (4) (1990), pp. 1171-1178.

Bulcroft and Teachman, $2004<$ R. Bulcroft and J. Teachman, Ambiguous constructions: development of a childless or childfree life course. In: M. Coleman and L. H. Ganong, Editors, Handbook of contemporary families, Sage Publications, Newbury Park, CA (2004).

Chandra et al., 20054 A. Chandra, A. G. Martinez, W. D. Mosher, J. C. Abma and J. Jones, Fertility, family planning, and reproductive health of U. S. women: data from the 2002 National Survey of Family Growth, Vital Health Statistics 25 (2005) (National Center for Health Statistics).

Chandra and Stephen, 1998 A. Chandra and E. H. Stephen, Impaired fecundity in the United States: 1982-1995, Family Planning Perspectives 30 (1998), pp. 34-42.

Chatters, $2000<$ L. M. Chatters, Religion and public health: public health research and practice, Annual Review of Public Health 21 (2000), pp. 335-367.

Congregation, 1987 Congregation for the Doctrine of the Faith, Donum vitae: Instruction on respect for human life in its origin and on the dignity of procreation; accessed June 2009 @ http://www.vatican.va/roman_curia/congregations/cfaith/documents/rc_con_ cfaith_doc_19870222 respect-for-human-life_en.html (1987).

Contrada et al., $2004<$ R. T. J. Contrada, T. M. Goyal and C. Cather, Psychosocial factors in outcomes of heart surgery: the impact of religious involvement and depressive symptoms, Health Psychology 23 (2004), pp. 227-238.

Dutney, 2007 A. Dutney, Religion, infertility, and assisted reproductive technology, Best Practice and Research Clinical Obstetrics and Gynaecology 21 (2007), pp. 169-180.

Ellison et al., $2008 \triangleleft$ C. G. Ellison, J. Lee, M. R. Benjamins, N. M. Kraus, D. N. Ryan and J. P. Marcum, Congregational support networks, health beliefs, and annual medical exams: findings from a nationwide sample of Presbyterians, Review of Religious Research $\mathbf{5 0}$ (2) (2008), pp. 176-193.

Ellison and Levin, $1998<$ C. G. Ellison and J. S. Levin, The religionhealth connection: evidence, theory, and future directions, Health Education \& Behavior 25 (1998), pp. 700-720.

Felix-Aaron et al., $2003 \varangle$ K. Felix-Aaron, D. Levine and H. R. Burstein, African American church participation and health care practices, Journal of General Internal Medicine 18 (2003), pp. 908-913.

Fox et al., 1998 S. A. Fox, K. Pitkin, C. Paul, S. Carson and N. Duan, Breast cancer screening adherence: does church attendance matter?, Health Education and Behavior 25 (1998), pp. 742-758.

George et al., $2002 \varangle$ L. K. George, C. G. Ellison and D. B. Larson, Explaining religious effects on health, Psychological Inquiry 13 (2002), pp. 190-200.

Grasmick et al., $1990<$ H. Grasmick, L. P. Wilcox and S. Bird, The effects of religious fundamentalism and religiosity on preference for traditional family values, Sociological Inquiry 60 (1990), pp. 352-369.

Greil, 1991 A. L. Greil, Not yet pregnant: Infertile couples in contemporary America, Rutgers University Press, New Brunswick, NJ (1991).

Greil and McQuillan, 2004 A. L. Greil and J. McQuillan, Help-seeking patterns among subfecund women, Journal of Reproductive and Infant Psychology 22 (2004), pp. 305-319.

Greil et al., 2009 A. L. Greil, J. McQuillan, K. Shreffler, K. M. Johnson, \& K. Slauson-Blevins, Explaining racial/ethnic disparities in helpseeking: The case of infertility. Paper presented at annual meeting of the Society for the Study of Social Problems, San Francisco, CA, 2009.

Hackney and Sanders, $2003<$ C. H. Hackney and G. S. Sanders, Religiosity and mental health: a meta-analysis of recent studies, Journal for the Scientific Study of Religion 42 (2003), pp. 43-55.

Hayford and Morgan, $2008<$ S. R. Hayford and S. P. Morgan, Religiosity and fertility in the United States: the role of fertility intentions, Social Forces 86 (2008), pp. 1163-1188.

Hill et al., $2006 \varangle$ T. D. Hill, C. G. Ellison, A. M. Burdette and M. A. Musick, Religious attendance and the health behaviors of Texas adults, Preventative Medicine 42 (2006), pp. 309-312.

Hirsch and Mosher, 19874 M. B. Hirsch and W. D. Mosher, Characteristics of infertile women in the United States and their use of infertility services, Fertility and Sterility 47 (1987), pp. 618-625.

Hoffmann and Bahr, 20054 J. P. Hoffmann and S. M. Bahr, Crime/ deviance. In: H. R. Ebaugh., Editor, Handbook of religion and social institutions, Springer, New York (2005), pp. 241-263. 
Hollingsworth, $2000 \varangle$ L. D. Hollingsworth, Who seeks to adopt a child? Findings from the National Survey of Family Growth (1995), Adoption Quarterly 3 (2000), pp. 1-23.

Holt et al., 2003a C. L. Holt, E. M. Clark, M. W. Kreuter and D. M. Rubio, Spiritual health locus of control and breast cancer beliefs among urban African American women, Health Psychology 22 (2003), pp. 294-299.

Holt et al., 2003b 4 C. L. Holt, S. N. Lukwago and M. W. Kreuter, Spirituality, breast cancer beliefs, and mammography utilization among urban African American women, Journal of Health Psychology 8 (2003), pp. 383-396.

Jacob et al., $2007 \varangle$ M. C. Jacob, J. McQuillan and A. L. Greil, Psychological distress by type of fertility barrier, Human Reproduction 22 (2007), pp. 885-894.

Jensen and Jensen, $1993<\mathrm{L}$. Jensen and J. Jensen, Family values, religiosity and gender, Psychological Reports 73 (1993), pp. 429-430.

Johnson and White, 20094 D. R. Johnson and L. K. White, National survey of fertility barriers methodology report; accessed May, 2009, from, Population Research Institute, Pennsylvania State University (2009) http:// sodapop.pop.psu.edu/data-collections/nsfb/dnd

Johnson et al., $2005<$ K. S. Johnson, K. I. Elbert-Avila and J. A. Tulsky, The influence of spiritual beliefs and practices on the treatment preferences of African Americans: a review of the literature, Journal of the American Geriatric Society 53 (2005), pp. 711-719.

Keeter et al., 20064 S. Keeter, C. Kennedy, M. Dimock, J. Best and P. Craighill, Gauging the impact of growing nonresponse on estimates from a national RDD telephone survey, Public Opinion Quarterly 70 (2006), pp. 759-779.

King and Pearson, $2003<$ D. E. King and W. S. Pearson, Religious attendance and continuity of care, International Journal of Psychiatry in Medicine 33 (2003), pp. 377-389.

Koenig and Larson, $2001 \varangle$ H. G. Koenig and D. B. Larson, Religion and mental health: evidence for an association, International Review of Psychiatry 13 (2001), pp. 67-78.

Koenig et al., $2001 \varangle$ H. G. Koenig, M. F. McCullough and D. B. Larson, Handbook of religion and health, Oxford University Press, New York (2001).

Koropeckyj-Cox and Pendell, 2007 T. Koropeckyj-Cox and G. Pendell, Attitudes about childlessness in the United States: correlates of positive, neutral, and negative responses, Journal of Family Issues 28 (2007), pp. 1054-1082.

Lewis and Rook, 19994 M. A. Lewis and K. S. Rook, Social control and personal relationships: impact on health behaviors and psychological distress, Health Psychology 18 (1999), pp. 63-71.

Mahoney et al., $2005 \varangle$ A. Mahoney, R. A. Carels, K. I. Pargament, A. Wachhholtz, L. E. Leeper and M. Kaplar et al., The sanctification of the body and behavioral health patterns of college students, International Journal for the Psychology of Religion 15 (2005), pp. 221-238.

McCarty et al., $2006 \triangle$ C. McCarty, M. House, J. Harman and S. Richards, Effort in phone survey response rates: the effects of vendor and client-controlled factors, Field Methods 18 (2006), pp. 172-188.

McCullough et al., $2000 \varangle$ M. E. McCullough, D. B. Larson, W. T. Hoyt, H. G. Koenig and C. Thoresen, Religious involvement and mortality: a meta-analytic review, Health Psychology 19 (2000), pp. 211-222.
Muramoto, $1999 \triangleleft$ O. Muramoto, Recent developments in medical care of Jehovah's Witnesses, Western Journal of Medicine 170 (1999), pp. 297-301.

Nagel and Sgoutas-Emch, 2007 E. Nagel and S. Sgoutas-Emch, The relationship between spirituality, health beliefs, and health behaviors in college students, Journal of Religion and Health 46 (2007), pp. 141-154.

Powell et al., $2003 \varangle$ L. H. Powell, L. Shahabi and C. E. Thoresen, Religion and spirituality: linkages to physical health, American Psychologist 58 (2003), pp. 36-52.

Rodin, $1990<$ J. Rodin, Control by any other name: definitions, concepts, and processes. In: J. Rodin and C. Schooler, Editors, Self-directedness: Cause and effects throughout the life course, Erlbaum, Hillsdale, NJ (1990).

Sandelowski, $19934 \mathrm{M}$. Sandelowski, With child in mind: Studies of the personal encounter with infertility, University of Pennsylvania Press, Philadelphia (1993).

Schenker, 20054 J. G. Schenker, Assisted reproductive practice: religious perspectives; accessed January, 2005 from, Reproductive Biomedicine Online (2005); http:/ / www.rbmonline.com/Article/1539

Schieman et al., $2006<$ S. H. Schieman, T. Pudrovska, L. I. Pearlin and C. G. Ellison, The sense of divine control and mental health in late life: moderating effects of race and socioeconomic status, Journal for the Scientific Study of Religion 45 (2006), pp. 529-549.

Schiller and Levin, $1988<$ P. L. Schiller and J. S. Levin, Is there a religious factor in health care utilization?, Social Science and Medicine 27 (1988), pp. 1369-1379.

Schmidt and Munster, 1995 L. Schmidt and K. Munster, Infertility, involuntary infecundity, and the seeking of medical advice in industrialized countries 1970-1992: a review of concepts, measurements and results, Human Reproduction 10 (1995), pp. 1407-1418.

Singer et al., 1998 E. Singer, A. Corning and M. Lamias, The pollstrends: genetic testing, engineering, and therapy: awareness and attitudes, Public Opinion Quarterly 62 (1998), pp. 633-664.

Straughan and Seow, $1998 \triangleleft$ P. T. Straughan and A. Seow, Fatalism reconceptualized: a concept to predict health screening behavior, Journal of Gender, Culture, and Health 3 (1998), pp. 85-100.

Straughan and Seow, $2000 \triangleleft$ P. T. Straughan and A. Seow, Attitudes as barriers in breast screening: a prospective study among Singapore women, Social Science \& Medicine 51 (2000), pp. 1695-1703.

Throsby and Gill, $2004<\mathrm{K}$. Throsby and R. Gill, "It's different for men": masculinity and IVF, Men and Masculinities 6 (2004), pp. 330-348.

White et al., $2006 \varangle$ L. White, J. McQuillan, A. L. Greil and D. R. Johnson, Infertility: testing a help-seeking model, Social Science and Medicine 62 (2006), pp. 1031-1041.

Williams, $2006<$ R. Williams, Generalized ordered logit/partial proportional odds models for ordinal dependent variables, The Stata Journal 6 (2006), pp. 58-82; pre-publication version available @ http://www.nd.edu/ rwilliam/gologit2/gologit2.pdf

Winship and Mare, $1984 \varangle$ C. Winship and R. D. Mare, Regression models with ordinal variables, American Sociological Review 49 (1984), pp. 512-525.

Zarit et al., 20024 S. H. Zarit, L. Pearlin and K. W. Schaie, Mastery and control in the elderly, Springer Publishing Co, New York (2002). 